\title{
More public and less experts: a normative framework for re- connecting the work of journalists with the work of citizens
}

\author{
Marietjie Myburg
}

'The god term of journalism - the be-all and end-all, the term without which the entire enterprise fails to make sense - is the public. Insofar as journalism is grounded, it is grounded in the public' ( James Carey).

\begin{abstract}
The potential of journalists to build a habit of participative and informed political discussion between government and citizens and between citizens and citizens has been eroded by a breakdown in trust between citizens and journalists. This breakdown is in part due to journalists being seen as experts favouring other experts as sources and marginalising the views of citizens - not just in relation to the covering of events but also in the investigation of possible solutions to public problem solving. This mirrors technocratic and expert-driven tendencies in government which further alienate citizens from the political process.

This essay uses three theoretical frameworks - democratic professionalism, public journalism and deliberative democracy - to explore the effects of expert-driven professionalism both in the state and in journalism and the implications of this approach for the relationship between journalists and citizens. It proposes that a shift in the way journalists consider their professional role could lead to a re-assessment of the political work of journalists and the political work of citizens and build new habits of participation and discussion in the political process of communities.
\end{abstract}

Key words: citizens, civic engagement, deliberation, democracy, democratic professionalism, expert-driven professionalism, objectivity, political process, public journalism.

\section{Introduction}

In a democracy, journalists have a crucial role to build a habit of participative and informed political discussion. Building this habit requires a relationship of trust between citizens and journalists. These 'bonds of confidence' (Waisbord, 2006:77) are complex and rest on more than good performance from the side of journalists. The normative rules of 'neutral, informative reporting of events' (McQuail, 2005:355), the 'occupational ideology' of objectivity (Deuze, $2005: 443$ ) or the classic concept of a 'marketplace of ideas' also need to be reassessed in order to restore lost trust. These features, set in a paradigm of liberal democracy, are part of a professional tradition that has made assumptions about what constitutes a trustworthy relationship with citizens. Waisbord (2006:76-7) argues that one example of such an assumption 
is that 'watchdog reporting' contributes positively to public trust. He points to evidence in Latin America which shows that public trust was high at times when journalists exposed corruption and while the media continued these exposés public trust diminished considerably. Investigative journalism in itself does not seem to be the only element of ensuring trust between citizens and the media.

The problem with representative or liberal democracy, says Barber ((2000:48), is that it turns politics into 'an activity of specialists and experts' operating in an 'instrumentalist setting' where their representation of citizens remains 'an abstraction' (Barber, 2000:449). Voltmer (2006:3) argues that in a liberal understanding of media in democracy the media are assigned a "passive role' of neutrally conveying competing views but that this often translates in reflecting the views of those who are able to voice their arguments most effectively. This model has proven inadequate if the media are to play a role in strengthening the kind of civic voice that is necessary in political systems where popular decision making is part of the political process and where the 'competence and rationality of citizens is of utmost importance' (Voltmer, 2006:4).

In the ever evolving work of democracy the professional habits of journalists to frame events in terms of expert views and what experts planned to do (Cunningham, 2003:29), have come to mirror the technocratic and expert driven approaches of political and government leaders. In the same way that this approach to politics has resulted in a disconnection between citizens and government, this approach has driven a wedge between citizens and journalists. This mode of news production has created an impression that journalists 'give meaning to their newswork' (Deuze, 2005:444) solely from an expert perspective. Instead of relying on journalists to protect their interests 'over and above the mere aggregation of 'particularistic interests' (Voltmer, 2006:5) citizens now view journalists as part of a 'powerful class of knowing people' who 'decode and interpret the universe of knowledge' (Petersen, 2003:255) on their behalf.

This information model renders the media 'a major political actor with tremendous power' (Mathews, 1994:19) and reduces citizens to the disempowering position of 'eavesdroppers' on a 'conversation between experts' (Campbell, 2000:691). This denies the potential of citizens to contribute to political process 'as experts in their own lives and as authorities on their own aspirations’ (Campbell, 2000:691).

This article explores the effects of expert driven professionalism both in the state and in journalism on the relationship with citizens in general and the 'authenticity of democracy' (Dzur, 2008:14) in particular. It proposes that a shift in the way journalists consider their professional role could lead to a reassessment of the political work of journalists and the political work of citizens and build new habits of participation and discussion in representative democratic process.

Three theoretical frameworks will be used to explore the potential of shaping a more constructive relationship between journalists, citizens and the state:

- Democratic professionalism is a fairly recent development in the field of political theory and addresses the politics of professionalism. It recognizes the 'democratic significance' (Dzur, 2008:3) of professions like journalism and proposes that this has implications for the way in which these professionals engage with citizens 
- Public Journalism, sometimes called civic journalism, comes from a framework developed by a group of journalists and media academics in the late 1980s proposing that the framing of public issues should place citizens at the centre (Rosen, 1997:21). While the public journalism movement has been criticized by both scholars and fellow journalists, the approach remains a valuable framework for how the work of journalists can be a catalyst for change by identifying, describing and analyzing social issues in a way that enables citizens to regain political agency and work together to address the problems they face

- Deliberative democracy recognizes the capacity of citizens to organize in a system of self-government, make choices together and face the consequences of these choices (Mathews, 1999:3). It acknowledges the role of journalists as an integral part of this process to 'give people voice and enable them to shape their world together' (McAfee, 2008:1).

\section{The alienating effect of expert-driven democratic representation}

'We complained about poor service delivery and what we got was an IDP.' ${ }^{1}$ This statement by a protestor in Phumelela township, quoted in a Business Day article (Bernstein, 2007) based on a Centre for Development and Enterprise (CDE) report, is most telling of the technocratic approach that has come to characterise the South African government's approach to solving the problems of service delivery. In the article, Bernstein (2007) quotes the Phumelela protestor to illustrate the 'gap between the world of expensive consultants who draw up plans and move on and the reality of citizens' daily lives'. In the report the Centre recommends that the government should re-examine the 'national department's fixation on paper IDPs'.

IDPs have become one of the modes in a technocratic problem solving approach that leaves citizens feeling 'removed from government' and, while demanding more, feel less willing to make a contribution 'through their own action and initiative' (Memela, Mautjane, Nzo, \& Van Hoof, 2008:1).

This failure of realising a democratic utopia where all citizens - including decision makers, experts - have equal power in shaping the state is of course not peculiar to South Africa. Globally, at a time when democratic ideals are promoted enthusiastically and in some cases even imposed by force, states grapple with the meaning of democracy. Democracy may manifest in different forms but it remains a 'public ideal' (Fischer, 2003:45) and the 'unexpected magnitude' of emerging democracies in Eastern Europe, Russia, Latin America and Africa offer new opportunities for scholars to study transitions and develop new understandings for the configuration of citizens, governments and political parties (Voltmer, 2006:1-2) and the role of journalists in this configuration.

In South Africa, the institutional demands on government to transform from apartheid to a country 'characterized by the antithesis of all that was bad' about that system (Ramphele, 2008:13) are enormous and tensions between the state and its citizens during the transformation

\footnotetext{
${ }^{1}$ Local municipalities in South Africa have to use 'integrated development planning' or IDP as a method to plan future development in their areas http://www.etu.org.za/toolbox/docs/localgov/webidp.html\#planning
} 
process are to be expected. What is unexpected, after a long and proud history of active citizen participation in undoing the apartheid system, is the lack of a public sphere - in both the Habermasian sense of lexis or discussion and praxis or common action (Habermas, 1989:3) providing citizens with opportunities to contribute as equal partners in the transformation project. Instead of building on and sustaining the features of the public sphere that did exist in the arena of contestation before 1994 and actively pursuing the potential of creating novel features for a public sphere appropriate to the demands of the emerging South African democracy, the government increasingly defines its governance role in technical terms and relies on expert consultants to determine the priorities of services to citizens.

Media scholars (Jacobs, 2002 \& Wasserman \& De Beer, 2006) illustrate a similar approach to changes in the media environment. While there have been important efforts to democratise the media landscape in South Africa, these changes remain largely fixated on legislative and corporate adjustments with very little to back it up in terms of how these changes fundamentally serve the interest of 'nation' and 'public' (Wasserman et al, 2006:70).

Jacobs (2002:2-3) makes the link between the power of experts and ideology when he analyses media ownership patterns, profit motives, employment practices and the commercialisation of the public broadcaster in terms of a neo-liberal 'brand of democracy' which favours individual rights and a diminished role for the state. Instead of 'providing sites where citizens can engage in the political process' this ideological model demobilises people and limits their participation in political process to election cycles (Jacobs, 2002:9-10).

In this scenario, citizens become clients or customers or, in the words of Derrida $(2003: 36)^{2}$ 'the silhouette of a phantom, the haunting fear of democratic consciousness'. Clients or customers suggest a different relationship with decision makers and political leaders than citizens. Ruiters (2006:129) argues that South Africa's public service charter, Batho Pele (People First), introduced a 'customer discourse' and 'terminology not usually associated with public goods discourse'. This includes references to citizens as 'users of services', 'customer surveys', 'globally competitive services' and 'value for money' to name but a few. The problem with this application of free market principles to delivery functions of the state is that this configuration of the state as business and citizens as customers results in divisions, which cannot easily be bridged with democratic values, like transparency, accountability or a free press. The state in this instance takes on the identity of the technical expert who keeps customers satisfied. Citizens, instead of seeing themselves as co-creators of public goods, take on an identity that is limited to being users of services defined merely in terms of satisfaction or dissatisfaction (Strom, 2005:2). Tasked with responsibilities that are increasingly of a technical nature requiring specialised expertise, government has come to view citizens as uneducated and ignorant of what it really takes to 'manage' a country.

\footnotetext{
${ }^{2}$ This essay is drawn from an interview Olivier Salvatori and Nicolas Weill conducted with Derrida in 1988. The interview first appeared in English in the book, The Other Heading: Reflections on Today's Europe, translated by Pascale-Anne Brault and Michael B. Naas. The article was published in the Kettering Review with permission from the Indiana University Press.
} 
Citizens respond by withdrawing from participation in political processes. Taking voter turnout as a measure of political participation, an SABC/Markinor survey (quoted in Barchiesi, 2004:2) shows the percentage of eligible South African voters who exercise their vote dropped from 85 percent in 1994, 64 percent in 1999 to 58 percent in 2004. This is just the thin end of a more worrying general trend of South African citizens losing interest in participating and interacting with government. Results of the Afrobarometer survey (Mattes, 2002:32) - a regular 12 country measure of Africans' views on democracy, markets and civil society - shows 6 percent of respondents reporting contact with a government or party leader in the previous year and 10 percent reporting contact with a community leader. These results are the lowest for this survey category in southern Africa and has led Mattes to conclude that South Africans have become 'one of the most passive citizenries in southern Africa' (2002:32). This, despite South Africa's reputation as one of the strongest democracies on the continent.

A survey by the Human Sciences Research Council (HSRC) shows a 'worrisome reversal' (Roberts, 2008) in citizens' trust in public institutions: between 2004 and 2007 trust in local and national government and in Parliament dropped by 20 percent and trust in political parties dropped by 16 percent. This is a further indication of a widening gap between citizens and government. Protest action by citizens in Phumelela and Khutsong over lack of services and the countrywide xenophobic attacks on migrants in the first half of 2008 carry the hallmark signs of action by citizens who feel disempowered and marginalised in decision making processes.

In his classic consideration of citizen capacity in state matters, Public Opinion, Lippmann (1922:17) dismissed the capacity of the public to have a 'competent opinion' on public affairs as an 'intolerable and unworkable fiction'. His prognosis was that citizens at their best were prone to manipulation and at worst overwhelmed by public affairs and too incompetent to grasp the complexities of their own problems to do something about it. The political world, he suggested, was 'out of reach, out of sight, out of mind' of most citizens and should be left to the 'expert organization'. But as Cortés (1996:48) points out, not only do experts often lack the answers to the 'complex technical questions' confronting public life but they have also proved to be prone to being guided by ideology in their choices while pretending to be led by neutral and scientific expertise. Which is why citizen participation to contribute 'normatively to the legitimization of policy development and implementation' is so important (Cortes, 1996:46).

When citizens accept or take on the identity of customers they abdicate their responsibility as cocreators of a democratic society to the experts. Corrupted by 'powerlessness' (Cortes, 1996:37) they doubt their own capacity and agency to make constructive contributions and to be partners in making the whole society work better.

\section{The alienating effect of expert-driven journalism}

Lippmann was as pessimistic about the ability of journalists to contribute to public life as he was of citizens. Like the public, Lippmann suggested newspapers could not be trusted with task of expressing competent opinion and therefore 'public opinions must be organized for the press if they are to be sound, not by the press as is the case today' (Lippmann, 1922:17). This pretty much set the tone for a professional mode which is alive and well more than a hundred years later. 
There is evidence of a growing disconnect between the South African media and citizens. The institutional framework that governs the South African media as described by Jacobs (2002:2-9) and Wasserman \& De Beer (2006:60-72) explain some, if not all of this discontent. Fourie (2003:154) quotes a survey from the SABC 2000/2001 annual report (these data do not appear in later annual reports) which shows that only 19 percent of the adult population believes newspapers are a credible source of news. While the same survey shows that citizens do consider the South African Broadcasting Corporation as a credible source of news, this trust is also waning. The report quoted by Fourie reflects survey results for 2000/01 at 91 percent for adults regarding news from the public broadcaster as 'most believable'. The HSRC survey (Roberts, 2008) quoted earlier in this article, measuring the level of trust in public institutions, found that in 2003, 75 percent of citizens said they trusted the SABC as a public institution and by 2006 this dropped to 72 percent. While the instruments for the SABC survey quoted by Fourie and the HSRC survey may have measured different aspects of trust and therefore presented different results, it is still fair to concur that in terms of the broad concepts underpinning trust as a value, the trend is downwards.

This is part of a global decline of citizen confidence in the media. In Latin America opinion polls in the 1980s and 1990s showed levels of trust ranging between 80 and 90 percent. By the first half of the new millennium these levels have slipped to around 50 percent (Waisbord, 2006:76). Merritt (1995:xv) cites a Yankelovich Monitor survey which shows that US citizens' confidence in television and print media declined by more than 50 percent in the 5-year period 1988-1993: television from 55 to 25 percent; newspapers from 50 to 20 percent and magazines from 38 to 12 percent. From this Merritt concludes: 'People will not place trust in something they feel is not helpful to them in solving their problems.'

Journalists are not unwilling to work with and on behalf of citizens. In their book, The Elements of Journalism, Kovach and Rosenstiel (2007:5-6) refer to citizens twice in what the authors propose to be the ten elements of journalism or the "principles that have helped both journalists and the people in self-governing systems to adjust to the demands of an ever more complex world'. The first reference is in terms of journalists' relationship to citizens: 'Its first loyalty is to citizens.' The second reference is a new addition to the original nine elements that they proposed in the first edition of the book: 'Citizens, too, have rights and responsibilities when it comes to the news'. These are important indicators of the primary relationship that guides news selection and presentation: 'the god term of journalism ... the public' (Carey, 1987:5).

Why is it then that, despite the intentions of journalists to do their work in the interest of citizens - as 'watchdogs', as the 'fourth estate' - there seems to be a persistent cloud of mistrust hanging over the relationship between citizens and journalists?

The tension journalists experience between being engaged while at the same time keeping an 'objective' and 'neutral' distance, may answer part of the question. McQuail (2005:563) concedes that objectivity may be a 'theoretically contested' term but he maintains that, for most journalists it lies at the heart of their professional relationship of 'trust and reliability' with media users. While these may be normative standards of good reporting, these standards, paradoxically, could also be blamed for the breakdown of trust between journalists and the public. It is not that objectivity and neutrality have become invalid standards for good journalism. The problem is, 
that in a news environment driven by the pressures inherent in a framework of political economy, these standards have become the thin end of 'both sides of the story' when journalists, forced by urgency to get the story and get it out before anyone else, now favour expert sources because information from these sources is readily available and usually reliable and credible enough to fulfil the be-all and end-all requirement of 'balanced reporting'. This has perpetuated a habit of 'spending too much time with power brokers and not enough time with ordinary citizens' (Elshtain, 1996:24) and, instead of seeing journalists as guardians of the public and therefore also their interest, citizens see journalists as 'conduits for relaying truth arrive at ... by the experts' (Carey, 1987:7).

\section{Democratic professionalism as an alternative to expert driven approaches}

Trust between journalists and citizens, says Waisbord (2006:77) cannot be understood simply in terms of how journalists serve democratic goals by holding governments accountable through investigative reporting. Neither can it be based on assumptions of what constitutes professional authority when performance standards are 'unilaterally determined by journalists or press analysts' (Waisbord, 2006:77). Waisbord continues to argue:

Trust in the press rests on specific expectations and whether those expectations are met. Consequently, for the press (or a specific news organisation) to be trusted, it does not necessarily have to perform according to prescriptions of what 'the good journalism' should be. Rather, it needs to meet citizens' expectations, which may or may not resemble any of the requirements established in press models.

These assumptions of 'professional authority' have always been, at best, rather 'ambiguous' (Dzur, 2008:135) and at worst, quite divisive in how it manifests in schisms between journalists writing for 'educated people who prefer thoughtful political and economic coverage' and those who cover the 'popular crime-scandal-celebrity mix' (Thisela, 2005:58).

Democratic professionalism forces journalists (and other professions such as the judiciary and health care) to reconsider existing performance models and commit to sharing authority and knowledge in order to become 'enabling intermediaries between citizens and the social and political institutions that affect them' (Dzur, 2008:136).

While the debilitating effect of expert driven technocratic approaches has been the focus of scholarly critique for a number of years, the ability of professional actors to 'expand rather than shrink democratic authority' (Dzur, 2004:6) has been unexplored. Democratic professionalism proposes that journalists count among these professional actors with a democratic responsibility to 'enable rather than disable citizen participation within their spheres of professional authority' (Dzur, 2004:6). This approach, says Rosen (1996:26), requires of professionals to reconsider their relationship with citizens: do journalists 'know' on behalf of citizens because citizens are incapable of knowing or 'is the professional the full-time inhabitant of a world that everyone ought to inhabit part-time as a citizen to make sense of problems and choices?'

Democratic professionalism is not a 'deprofessionalization or anti-institution movement' (Dzur, 2008:3). Rather, it values the specialised knowledge required to do a particular job while at the same time using and sharing this knowledge to build 'well-integrated political communities 
organized around a knowledgeable citizenry' (Fischer, 2003:47). At the same time it acknowledges the specialised knowledge that exists among citizens and adopts an approach that galvanizes that knowledge and cultivates confidence in citizens' civic competency instead of an approach that undermines citizens' trust in their own and the capacity of collective action with fellow citizens (Dzur, 2008:95-6)

\section{The potential of public journalism to reconnect citizens and journalists}

Spending time with citizens or citizen connectedness is the rallying point of public journalism as a professional movement and a theoretical departure point. Sometimes called civic journalism, this model comes from a framework developed by a group of journalists and media academics in the late 1980s proposing that the framing of public issues should place citizens at the centre (Rosen, 1997:21). While the public journalism movement has been critiqued by both scholars and fellow journalists, the approach remains a valuable framework for how the work of journalists can be a catalyst for change by identifying, describing and analysing social issues in a way that enables citizens to regain political agency and work together to address the problems they face. Jay Rosen, one of the main advocates and scholars of public journalism, describes the central theme of public journalism as the notion that journalists are members of the political community, citizens themselves and not bystanders to our public life' (1997:3 [personal emphasis]).

From the perspective of 'deeply entrenched professionalism' public journalism's call for a more active role for journalists in supporting civic involvement, even going as far as including citizens in the development of news stories look 'propagandistic' (St. John, 2007:249). But far from being propagandistic or compromising objectivity and neutrality Rosen argues that public journalism 'strives for a deeper level of fairness' by consciously considering the framing power of news. He talks about a 'positioning effect' of news stories (1997:18-19) and maintains that journalists routinely make decisions about how to portray people in news coverage as 'fans, victims, celebrants, consumers or sentimentalists'. In this regard, reporting on HIV and AIDS is a good example of how journalists have consciously opted for positioning people infected with the AIDS virus as 'people living with AIDS' or 'living positively' rather than people dying from a terminal illness. In this case 'positioning' has never been regarded as compromising objectivity or neutrality but rather as a device for deepening or broadening understanding for the affected subjects in the stories. Similarly, public journalism proposes that journalists consciously frame or 'position' citizens at the centre of political process. The alternative, says Rosen, is a 'balanced' story which often perpetuates people in a position of 'helpless spectators' because there is 'no room for ambivalence, no place where many of us might want to stand' (Rosen, 1997:19).

This willingness to produce news from the place where citizens may stand and not from where the experts stand may be public journalism's most valuable contribution to get journalists to reconsider their 'aversion to civic engagement' (St. John, 2007:250). It is an attitude that holds democratic hope for the practical potential of journalists to be catalysts of change when they enter into a 'reciprocal' (Derrida, 2003:42) relationship with fellow citizens. Chomsky (1996:50) suggests that, in a democratic society, the media would be under 'public control'. This, according to him, means that the public will participate - 'to the extent that people want to be involved'. McAfee (2008:7) considers two possible ways of viewing the media when she distinguishes 
between a 'cynical' and a 'hopeful' narrative of democracy - the former stemming from the philosophic traditions of, among others, Lippmann, and the latter from, among others, the philosopher John Dewey who was Lippmann's peer but held more hope for the capacity of citizens to make a contribution to public life. In McAfee's distinction, the cynical version of democracy includes a view of the media as a manipulative force; in the hopeful version the media 'provide ways for people to communicate, to make their inner worlds part of a public and human world, to help shape and direct the public world' (McAfee, 2008:6). This description captures the ideals and the practice of a public journalism approach. It is an approach that is committed to finding practical ways of developing professional habits that connect journalists to the civic and political process of citizens in their communities ${ }^{3}$. It changes the relationship of journalists from working for citizens to with citizens and rather than leading the public to facilitating understanding of public issues and political process. It is, as Merritt puts it, 'an attitude that becomes a way of doing, not simply a way of doing' (1997:27).

The 'way of doing', or putting the approach in practice is the challenge. Rosen suggests that framing stories in a way that 'fortify public life, civil participation and deliberative dialogue' is the key to the pragmatic value of public journalism (1997:15). Journalism as a profession is steeped in a gatekeeper tradition where journalists 'filter through the happenings of the world, select the significant events, and report them for their audience' (Nip, 2006:216). And while it may be 'an idea seeking meaningful application rather than a set of operational principles or set of rules' (Merritt, 1997:27) it is important to generate more research to empirically assess this approach and its potential impact. Bare (1998:85), suggests three areas of inquiry: editorial content, practice and behaviour of journalists in gathering and reporting news and attitudes and beliefs of reporters and editors.

A review of the institutional environment in which journalists work starts with the consideration of the 'political implications of [their] professional knowledge and practice' (Dzur, 2008:6). Journalists, says Katz (1996:23), should spend time in those 'central' and 'dispersed spaces' of participatory democracy 'dedicated to the polity as a whole and ... to the citizens' need to know what like- or right-minded others are thinking'. Both these views suggest that journalists, as citizens, cannot escape or avoid being part of the 'metanarrative of empire and control'. They are not distant bystanders or detached observers of political process, they are part of it, they contribute to it, they are at the very heart of what this political process should and could look like.

\section{The work of citizens in political process}

If Lippmann found citizens incapable of participating in democratic decision making, his peer and critic, John Dewey, took the opposite view. Rosen (1996:24) describes Dewey's proposal of democracy as public 'intelligence' that will emerge under conditions which are co-created by

\footnotetext{
${ }^{3}$ For the purpose of this article Cortés' (1996:32) definition of politics applies: '...Politics is about relationships that enable people to disagree, argue, interrupt, confront and negotiate and, through this process of conversation and debate, to forge consensus or compromise that makes it possible for them to act.'
} 
citizens as a 'path of democratic hope'. This suggests a democratic role for citizens that go beyond voting. It is the hard work of defining problems, making choices, taking action and reflecting on the consequences of these actions with other citizens. Where citizens abdicate this work to politicians or other experts - including the media - citizens are marginalized from but also marginalise themselves from political process. This undermines the potential of democracy as a system of 'self government' (Coetzee \& Graham, 2002:4-5).

Deliberative democracy as a model for citizen participation in political process has been the focus of democratic theorists since the 1990s (Dzur, 2008:14). Also described as a movement, (Gastil \& Keith, 2005:3) this model accepts the value of systematic and planned opportunities for citizens to discuss public, and by implication, political, issues. Citizens, even when voting patterns or other opportunities for political participation suggest otherwise, want to be involved in political process and deliberative democracy offers them a way back into the system (Mathews, 1999:28). McAfee (2005:91-99) distinguishes three models of democratic deliberation:

- A preference-based model in which citizens see democracy as a means to maximise individual preferences and where the purpose of deliberation is developing individual opinions and preferences

- A rational proceduralist model which specifies 'rational' and 'acceptable' reasoning and procedures to ensure a positive result; and

- An integrative model which sees deliberation as a process in which participants "grapple" with choices for solving public problems not through considering their individual preference but in terms of effect on the whole community.

The integrative model is the model that holds most promise for 'common ground for action' but McAfee warns that this approach does not aim for 'happy consensus'. Rather, it requires the 'pragmatic task of delineating what courses of action might work given polity members' many aims and constraints' and the hard work of 'fathoming problems and forming a public that can respond' (McAfee, 2005:100). This suggests citizens at work or as Elshtain ((1996:32) puts it: 'Democracy is about an ethos, it is a way of responding, it is the emergence of civically shaped characters. And to be one such you have to get out of the house and into the community.'

\section{Conclusion}

This essay illustrates the inhibiting effect on active citizenship of technocratic and expert driven approaches to problem solving in democracies or systems of self government. This approach is not limited to government and public officials but has also been adopted by other democratic institutions, like the media.

The work of journalists are weighed down by organisational and structural pressures resulting from an operational framework demanding the freshest news fastest and produced by fewer people. In this milieu journalists opt for sources that are available and carry a stamp of credibility and approval - usually experts in their fields or people in power. Despite their best intentions to be guardians of citizens' interests, this scenario has alienated citizens from journalists. Citizens 
don't consider journalists as allies but are rather suspicious and cynical of the information they read in newspapers and hear and see on the news.

This essay suggests that the public journalism model may offer some potential to re-connect journalists with citizens who are losing interest in the news because they feel that it has no use for them in making the decisions they need to make about the public problems that confront them. More information is necessary on the operational implications of public journalism or pragmatic guidelines to steer the work in newsrooms. These guidelines should be based on more empirical research about the impact of citizen centred approaches to news production. The essay suggests some questions for inquiry. More empirical information is also required to consider the professional identity of journalists and how that affects the way they approach their work.

Finally the work of citizens in political process is considered as complementary to the work of journalists. The model of deliberative democracy, which involves citizens in the hard work of building and sustaining healthy civic life, is proposed as a way citizens can re-enter the realm of politics - where they belong as vital partners in political process and systems of self-government.

\section{Author details:}

Marietjie Myburg is a MPhil (Journalism) student at Stellenbosch University.

\section{Contact details:}

(mmyburg@idasa.org.za)

P.O. Box 927, Houghton, 2041

Tel: +27 12 3920500; Fax: +2786 6333222

\section{References}

Barber, B. (2000). Strong democracy: politics in the participatory mode. In: R. Blaug \& J. Schwarzmantel (Eds.), Democracy: a reader (447-451). New York: Columbia University Press

Barchiesi, F. (2004). Classes, multitudes and the politics of community movements in postapartheid South Africa (No. 20). Durban South Africa: Centre for Civil Society.

Bare, J. (1998). A new strategy. In: E. B. Lambeth, P. E. Meyer \& E. Thorson (Eds.), Assessing public journalism (83-108). Columbia Missouri: University of Missouri Press.

Bernstein, A. (2007). South Africans tired of paper fairy tales. Business Day, 2007-0508:11.

Campbell, C. C. (2000). Citizens matter: and that is why public journalism matters. Journalism Studies, 1(4): 689-694.

Carey, J. W. (1987, March/April ). The press and the public discourse. The Center Magazine, 416. 
Chomsky, N. (1996). The common good (2003 ed.). Tucson Arizona: Odonian Press.

Coetzee, A. \& Graham, P. (2002). In the balance - debating the state of democracy in South Africa. Cape Town: Idasa.

Cortes, E. (1996). Reweaving the social fabric. Kettering Review (Summer 1996): 31-38.

Cunningham, B. (2003). Re-thinking objectivity: in a world of spin, our awkward embrace of an ideal can make us passive recipients of the news. Columbia Journalism Review, 42(2): 24-34.

Derrida, J. (2003). Call it a day for democracy. Kettering Review, 2003(Fall): 36-43.

Dzur, A. W. (2004). Democratic professionalism: sharing authority in civic life. The Good Society, 13(1): 6-14.

Dzur, A. W. (2008). Democratic professionalism: citizen participation and the reconstruction of professional ethics. University Park Pennsylvania: Pennsylvania State University Press.

Elshtain, J. B. (1996). Democracy and the news: citizens, journalists and contemporary politics. Paper presented at the Alfred I. duPont Forum.

Fischer, F. (2003). Citizens, experts, and democracy. Kettering Review (Fall): 44-52.

Fourie, P. J. (2003). The future of public service broadcasting in South Africa: the need to return to basic prinicples. Communicatio, 29(1\&2): 148-181.

Gastil, J. \& Keith, W. M. (2005). A nation that (sometimes) likes to talk. In J. Gastil \& P. Levine (Eds.), The deliberative democracy handbook - strategies for effective civic engagement in the 21st century (3-19): Jossey-Bass.

Habermas, J. (1989). The structural transformation of the public sphere - an inquiry into a category of bourgeois society (T. Burger, Trans. 1991 ed.). Cambridge Massachusetts: The MIT Press.

Jacobs, S. (2002). How good is the South African media for democracy? Mapping the South African public sphere after apartheid. Unpublished research paper. Transregional Center for Democratic Studies New York.

Katz, E. (1996). And deliver us from segmentation. The ANNALS of the American Academy of Political and Social Science, 546(1): 22-33.

Kovach, B., \& Rosenstiel, T. (2007). The elements of journalism. New York: Three Rivers Press. 
Lippmann, W. (1922). Public opinion (2004 ed.). New York: Dover Publications, Inc.

Mathews, D. (1999). Politics for people (2nd ed.). Dayton, Ohio: The Kettering Foundation.

Mattes, R. (2002). South Africa: democracy without the people? Journal of Democracy, 13(1): 22-36.

McAfee, N. (2005). Three models of public deliberation. In: R. J. Kingston (Ed.), Public thought and foreign policy: essays on public deliberations about Americans' role in the world (90106). Dayton, Ohio: Kettering Foundation Press.

McAfee, N. (2008). Beyond manipulation: democracy and media. Kettering Foundation.

McQuail, D. (2005). McQuail's mass communication theory. London, Thousand Oaks, New Delhi: Sage Publications.

Memela, S., Mautjane, B., Nzo, T. \& Van Hoof, P. (2008). The state of local governance in South Africa: what does the Local Governance Barometer tell us. Pretoria: Idasa.

Merritt, D. B. (1995). Public journalism and public life. Hillsdale New Jersey: Lawrence Erlbaum Associates.

Merritt, D. B. (1997). Public journalism: where it has been; where it is headed. In C. Gibbs (Ed.), Public journalism: theory and practice - lessons from experience (25-35). Dayton Ohio:

Kettering Foundation.

Nip, J. Y. M. (2006). Exploring the second phase of public journalism. Journalism Studies, 7(2), 212-236.

Petersen, J. H. (2003). Lippmann revisited: a comment 80 years subsequent to "Public Opinion". Journalism, 4(2), 249-259.

Ramphele, M. (2008). Laying ghosts to rest - dilemmas of the transformation of South Africa. Cape Town: Tafelberg.

Roberts, B. (2008). Between trust and scepticism - public confidence in institutions. HSRC Review. Retrieved from www.hsrc.ac.za/HSRC_Review_Article-85.phtml

Rosen, J. (1996). Public scholarship. Higher Education Exchange, 1996, 23-38.

Rosen, J. (1997). Public journalism as a democratic art. In C. Gibbs (Ed.), Public journalism: theory and practice - lessons from experience (pp. 3-24). Dayton, Ohio: The Kettering Foundation. 
Ruiters, G. (2006). South Africa: public services: transformation or stasis. In D. Chavez (Ed.), Beyond the market: the future of public services (pp. 127-135). Amsterdam: Transnational Institute.

St. John, B. (2007). Newspapers' struggle with civic engagement: The US press and the rejection of public journalism as propagandistic. The Communication Review, 10(3), 249-270.

Strom, M. (2005). Citizens at the Centre - AIDS Councils as catalysts for unlocking citizen power. Pretoria: Idasa.

Thisela, N. (2005). Bloom and doom of the rising sun. Stellenbosch Media Forum, 57-59.

Voltmer, K. (2006). The mass media and the dynamics of political communication in processes of democratization. In K. Voltmer (Ed.), Mass media and political communication in new democracies (pp. 1-20). London \& New York: Routledge.

Waisbord, S. (2006). In journalism we trust? Credibility and fragmented journalism in Latin America. In K. Voltmer (Ed.), Mass media and political communication in new democracies. London and New York: Routledge.

Wasserman, H., \& De Beer, A. S. (2006). Conflict of interest? Debating the media's role in postapartheid South Africa. In K. Voltmer (Ed.), Mass media and political communication in new democracies (pp. 59-75). New York: Routledge. 